\title{
Preingestive selection processes in the cockle Cerastoderma edule: mucus production related to rejection of pseudofaeces
}

\author{
M. B. Urrutia*, E. Navarro, I. Ibarrola, J. I. P. Iglesias \\ Animali Biologia eta Genetika Saila, Zientzi Fakultatea, Universidad del País Vasco/Euskal Herriko Unibertsitatea, PK 644, \\ 48080 Bilbao, Spain
}

\begin{abstract}
Feeding behaviour of Cerastoderma edule fed diets with different organic contents was studied under conditions that induced production of pseudofaeces. Cockles were fed suspended matter composed of cells of Tetraselmis suecica and inorganic particles of ashed sediment, and we measured the rates and efficiencies with which phytoplankton but also overall organic matter was processed both at pre- and postingestive level. Preferential ingestion of microphytoplankton was observed and derived benefits computed, under a framework whose main objective was to quantify the mucus involved in pseudofaeces rejection and its effect on selection processes. Energy losses in the form of mucus depended on the rate of pseudofaeces production but also on the organic content of filtered matter. Under feeding conditions characterised by high rates of rejection of filtered matter of low organic content, the production of endogenous organic matter in the pseudofaeces represented the main organic component. Consequently, lack of quantification of this term would definitively bias all calculations derived from computing the organic fraction of rejected matter. In particular, the reduction in the efficiency with which organic matter from the diet is selected under low seston organic content, reported in previous studies, was found to be a consequence of the presence of increased mucus in pseudofaeces and not an indicator of loss of efficiency in the sorting process. We have calculated that underestimation of 'true' rates of organic ingestion and absorption of dietary organic matter may be as high as 46 and $98.6 \%$, respectively, as a result of the assumption that the presence of mucus in the pseudofaeces is negligible. Finally, taking into account the energy loss in the form of mucus when pseudofaeces are produced, it is concluded that this energetic investment may be a major determinant of the feeding strategy of cockles.
\end{abstract}

KEY WORDS: Mucus · Pseudofaeces · Preingestive selection · Bivalves $\cdot$ Cerastoderma edule Resale or republication not permitted without written consent of the publisher

\section{INTRODUCTION}

The ability to limit the quantity of food ingestion by producing pseudofaeces is broadly known among bivalves. Associated to this feeding behaviour, preingestive selection processes have often been observed and quantified, and benefits derived from the preferential ingestion of some types of particles have been highlighted (Kiørboe \& Møhlenberg 1981, Newell \& Jordan 1983, Prins et al. 1991, Iglesias et al.

*E-mail: ggpurbam@lg.ehu.es
1992, Urban \& Kirchman 1992, Bayne et al. 1993, MacDonald \& Ward 1994, Hawkins et al. 1996, 1998b, Bacon et al. 1998). However, there is still one aspect related to the rejection of food as pseudofaeces that remains to be clarified: the quantification of mucus voided with those biodeposits and its effect on the parameters usually measured to characterise the feeding behaviour of suspension-feeding bivalves.

Production of mucins is a widely spread process among molluscs. Depending on the group considered, it may have different functions (see review by Davies \& Hawkins 1998). Participation of mucus in filtration and rejection processes in bivalves has been proved by

() Inter-Research 2001 
endoscope observations and confirmed by independent histochemical and chemical analysis (Beninger \& St-Jean 1997a,b, Beninger et al. 1991, 1992, 1993, 1997, Ward et al. 1993, 1994). However, most of the studies about preingestive selection have assumed that the quantity of mucus which is rejected with the pseudofaeces is negligible (MacDonald \& Ward 1994). For gastropods, where mucus production processes have been studied in more depth, it has been found that the amount of energy that goes from the animal into that component might be important, and it has even been suggested that those studies which did not take into account this loss term should be revised since they may considerably overestimate the amount of energy assimilated by the animals (Davies et al. 1990, Peck et al. 1993).

Lack of quantification of the contribution of mucus to pseudofaeces in bivalves is mainly due to the difficulties in determining the proportion of endogenous matter in biodeposits, but there is another reason: most of the studies are concerned with total energy balance. In such studies the origin of organic matter in the pseudofaeces is unimportant, since it is simply considered as an energy loss towards the environment. However, it is important to know precisely how much organic matter in the pseudofaeces is mucus to avoid confusion with other organic components and to make reliable estimates concerning the utilisation of the different particles of the seston. In this sense it has often been proposed (Iglesias et al. 1992, Navarro \& Iglesias 1993, Urrutia et al. 1996) that the presence of mucus in the pseudofaeces could be responsible for the decrease observed in the efficiency with which organic matter is selected when the quality of the seston is low, but as far as we know, this point remains unproven since mucus has not been measured until now.

The present study was designed to obtain an estimate of the quantity of mucus that cockles Cerastoderma edule reject with the pseudofaeces, with the aim to explain differences observed in the preingestive behaviour depending on which food component was under consideration (phytoplankton or overall organic matter), as well as to better understand different feeding strategies. The study of the utilisation of the microalga Tetraselmis suecica, both at pre- and post-ingestive level, as a function of the organic content of the diet, per se, was an additional objective of the work.

\section{MATERIAL AND METHODS}

Collection and conditioning of experimental animals. Cockles Cerastoderma edule were collected in the saltmarsh of Urdaibai estuary (Biscay, Spain) in late May and early June 1992. Selection based on shell height (25 $\pm 2 \mathrm{~mm}$ ) avoided great differences in size. In the laboratory they were individually placed in seawater-filled tanks. Temperature was kept at $16^{\circ} \mathrm{C}$, in agreement with the recorded field value.

Composition of artificial diets. Each diet used in this experiment was a particular mixture of ashed silt and cells of the microalga Tetraselmis suecica. Ashed silt was obtained by ashing sediment $\left(800^{\circ} \mathrm{C}, 12 \mathrm{~h}\right)$ collected at the same site as cockles: only the most superficial layer of sediment was collected $(0.5 \mathrm{~cm})$, being dried prior to ashing. Following removal of organic matter, particles were sieved; those larger than $45 \mu \mathrm{m}$ were discarded in an attempt to mimic the natural size distribution of the sediment. T. suecica cells were obtained from exponentially growing cultures of this species (f/2 Guillard medium).

Combination of different proportions of an organic matter source (Tetraselmis suecica) with pure inorganic matter (ashed silt) enabled us to obtain diets covering a wide range of organic contents (5 to $90 \%$ ). Letters from A to I were used to name diets arranged from low to high organic content (see Table 1). Concentrations of particles were established in terms of the packed volume of particles in suspension (after Bayne et al. 1987), which was fixed at $6.5 \mathrm{~mm}^{3} \mathrm{l}^{-1}$. For the monoalgal diet (Diet I) the packed volume of the suspension was kept at $9.5 \mathrm{~mm}^{3} \mathrm{l}^{-1}$, because pseudofaeces production up to that concentration was negligible. To ascertain the effect that such an increment in the concentration could exert, we decided to include another diet, called Diet $C$, with an organic content similar to Diet $B$, but in which particle concentration was also kept at $9.5 \mathrm{~mm}^{3} \mathrm{l}^{-1}$.

Diets were prepared as concentrated stocks that were delivered to experimental tanks by a peristaltic pump. Particles were kept in suspension using both magnetic agitation and bubbling. Packed volume of suspended particles was frequently measured, every 15 min approximately, by analysing samples taken from the tanks in a Coulter Multisizer provided with a $100 \mu \mathrm{m}$ tube; deviations from the reference value could thus be quickly corrected. Cockles were fed experimental diets for at least $18 \mathrm{~h}$ before we started measuring any parameter, to ensure complete elimination of food ingested in their natural habitat.

Characterisation of the diets. Replicate samples of water in the experimental tanks were taken every $2 \mathrm{~h}$ to measure both particle concentration and composition of suspended matter. Two aliquots were taken from each sample, the first to establish the concentration of chlorophyll a by the Lorenzen (1967) method, and the second to determine the total concentration of particles (TPM: $\mathrm{mg} \mathrm{l}^{-1}$ ) and organic fraction of suspended matter (POM: $\mathrm{mg} \mathrm{l}^{-1}$ ). Volume of aliquots was recorded prior to filtering through prewashed and preweighed glass fibre GF/C Whatman filters. 
Food processing. Faeces and pseudofaeces produced by each individual were collected separately. Successive collections of biodeposits from each animal were pooled, and statistical analyses were run using mean values for each individual as replicates.

Total and organic weight of each type of biodeposit was determined as for water samples. Time needed for production of biodeposits was recorded, and thus egestion rates for total and inorganic matter (Er and IEr: mg $\mathrm{h}^{-1}$ ) and rejection rates for both components ( $\mathrm{Rr}$ and IRr: $\mathrm{mg} \mathrm{h}^{-1}$ ) were calculated. When pseudofaeces production allowed it, an aliquot was taken to analyse chlorophyll content and, then, the rejection rate (ORr*) and the selection efficiency for algal matter (SEchl) were estimated.

Assuming the absorption of inorganic matter in the digestive system is negligible (Navarro \& Thompson 1994), filtration rate of inorganic matter (IFr: $\mathrm{mg} \mathrm{h}^{-1}$ ) was calculated as the sum: IEr + IRr. Then, applying the organic content of the suspension, filtration rates of organic (OFr: $\mathrm{mg} \mathrm{h}^{-1}$ ) and total matter $\left(\mathrm{Fr}: \mathrm{mg} \mathrm{h}^{-1}\right.$ ) were calculated.

Clearance rates $\left(\mathrm{Cr}: 1 \mathrm{~h}^{-1}\right)$ were estimated from values of filtration rate (Fr: $\mathrm{mg} \mathrm{h}^{-1}$ ) and values of concentration of suspended particulate matter (TPM: $\mathrm{mg} \mathrm{l}^{-1}$ ) according to the expression $\mathrm{Cr}=\mathrm{Fr} / \mathrm{TPM}$. Rates of ingestion of organic (OIr: $\mathrm{mg} \mathrm{h}^{-1}$ ) and total particulate matter (Ir: $\mathrm{mg} \mathrm{h}^{-1}$ ) were obtained by subtracting rejection from filtration rates. Absorption rates $\left(\mathrm{Ar}: \mathrm{mg} \mathrm{h}^{-1}\right.$ ) were finally estimated as the difference between organic ingestion and egestion rates, and, so, absorption efficiency (AE) could also be calculated as AE = Ar/OIr.

This methodology, as any other, leads to a certain underestimation in the computation of OIr and subsequent calculations when no quantification of the mucus of pseudofaeces is undertaken: calculation of corrected ingestion $\left(\mathrm{OIr}^{*}\right)$ and absorption $\left(\mathrm{Ar}^{*}\right)$ rates of organic matter as well as corrected absorption efficiencies $\left(\mathrm{AE}^{*}\right)$ requires the subtraction of mucus production from rejection rates, followed by its addition to ingestion and absorption rates.

Fitting of absorption efficiency. Since there was only 1 source of exogenous organic matter in the food, the (net) absorption efficiency $(\mathrm{AE}=\mathrm{AEn})$ should increase for increasing organic content of ingested matter (i) according to a hyperbolic function. This should be so because under conditions where the ingestion rate (Ir) is closely regulated, transit time of the food remains almost constant, and, therefore, gross absorption efficiency (AE $b$ ) results independent of changes in the quality of ingested matter. Reduction in the absorption efficiency (AEn) for diets of lower organic content would be caused by the increasing contribution of endogenous faecal losses (MFL) to the organic content of the faeces. This may be explained if we assume that MFL compose a constant proportion of total ingestion (MFL = aIr, Hawkins et al. 1990). If we take into account all the above considerations, AEn should be a linear function of the inverse of the organic content of $i$, i.e., it should adjust to a hyperbolic function of $i$. In effect AEn $=\mathrm{AE} b-\mathrm{MFL} / \mathrm{OIr}$, and if MFL = $a \mathrm{Ir}$, then AEn $=\mathrm{AE} b-a / i$, where $i=\mathrm{OIr} / \mathrm{Ir}$. Data were thus fitted to this kind of function.

Selection efficiency and benefit ratios. We considered 2 selection indexes, SEchl and SEo, as indicators of the efficiency with which phytoplankton (chlorophyll a) and overall organic matter were selected. These indexes were calculated according to the following expressions:

$$
\begin{gathered}
\text { SEo }=1-(p / f) \\
\text { SEchl }=1-(\operatorname{chl} p / \text { chl } f)
\end{gathered}
$$

where $p$ and $f$ are the organic contents of pseudofaeces and food, and chlp and chl $f$ are the chlorophyll contents of rejected and filtered matter, respectively.

Benefits derived from the preferential ingestion of overall organic matter but also chlorophyll were quantified by using the benefit ratio indexes applied to these components. Calculations were made according to the formulae:

$$
\begin{aligned}
\text { BRo } & =(\text { OIr }- \text { OIrnosel }) / \text { OIr } \\
\text { BRchl } & =(\text { chllr }- \text { chlIrnosel }) / \text { chlIr }
\end{aligned}
$$

where OIr and chlIr are the rates of organic and chlorophyll ingestion and OIrnosel and chllrnosel are the rates that would have been measured if selection mechanisms were not operating. Benefits obtained at the postingestive level were similarly measured, using the BRab benefit ratio, calculated as $\mathrm{BRab}=(\mathrm{Ar}-$ Arnosel)/Ar.

Relation of mucus production to rejection of filtered matter. Mucus production has been demonstrated to be a constant in the filtration process in bivalves, i.e., it also occurs when pseudofaeces are not being produced (Beninger et al. 1991, 1992, Ward et al. 1993). However, due to methodological limitations, we could only estimate the endogenous matter being voided while filtered matter was being rejected; we termed this parameter 'pseudofaecal mucus production'.

A quantitative estimation of mucus production during the rejection process could be obtained because diets with only 1 organic component of algal origin were used. We used the following approach: If mucus was absent in the pseudofaeces, rejected proportions of organic matter and chlorophyll, ORr/OFr and chlRr/chlFr, should be identical. Therefore, the corrected gross rejection rate of organic matter $\left(\mathrm{ORr}^{*}\right)$ could be derived as $\mathrm{OFr} \times$ chlRr/chlFr. The difference between the actual rejection rate of organic matter (ORr) and the rate calculated under the previous assumption $\left(\mathrm{ORr}^{*}\right)$ is, in fact, an esti- 
mation of the pseudofaecal mucus production rate $(\mathrm{Mr})$, such that $\mathrm{Mr}=\mathrm{ORr}-\mathrm{ORr}{ }^{*}$.

As an alternative, and especially for those cases in which all rates could not be measured, the pseudofaecal mucus production rate might also have been directly derived from the difference between selection efficiency indexes, total rejection rates and organic content of the diet, because, while selection efficiency of organic matter (net efficiency) is derived from the measurement of net organic content of pseudofaeces, mucus does not affect chlorophyll contents of biodeposits or seston, and, therefore, selection efficiency calculated for chlorophyll may be considered as a gross selection efficiency index. The difference between both indexes, when calculated for diets similar to those considered here, therefore, results only from the contribution of mucus to the organic content of pseudofaeces. A derivation of this is given in the following:

Since

$$
\text { SEchl }=1-\frac{\mathrm{chlRr} / \mathrm{Rr}}{\operatorname{chlFr} / \mathrm{Fr}} \text { and SEo }=1-\frac{\mathrm{ORr} / \mathrm{Rr}}{\mathrm{OFr} / \mathrm{Fr}}
$$

then

$$
\begin{aligned}
\text { SEchl-SEo } & =1-\frac{\mathrm{chlRr} / \mathrm{Rr}}{\operatorname{chlFr} / \mathrm{Fr}}-1+\frac{\mathrm{ORr} / \mathrm{Rr}}{\mathrm{OFr} / \mathrm{Fr}} \\
& =\frac{\mathrm{ORr} / \mathrm{OFr}-\mathrm{chlRr} / \mathrm{chlFr}}{\mathrm{Rr} / \mathrm{Fr}}
\end{aligned}
$$

thus

Since

$$
(\mathrm{SEchl}-\mathrm{SEO}) \times \frac{\mathrm{Rr}}{\mathrm{Fr}}=\frac{\mathrm{ORr}}{\mathrm{OFr}}-\frac{\mathrm{chlRr}}{\mathrm{chlFr}}
$$

$$
\mathrm{ORr}=\mathrm{ORr}^{*}+\mathrm{Mr} \text { and } \frac{\mathrm{chlRr}}{\mathrm{chlFr}}=\frac{\mathrm{ORr}^{*}}{\mathrm{OFr}}
$$

then

$$
(\mathrm{SEchl}-\mathrm{SEo}) \times \frac{\mathrm{Rr}}{\mathrm{Fr}}=\frac{\mathrm{ORr}^{*}+\mathrm{Mr}-\mathrm{ORr}^{*}}{\mathrm{OFr}}
$$

and therefore

$$
(\mathrm{SEchl}-\mathrm{SEO}) \times \mathrm{Rr} \times f=\mathrm{Mr}
$$

Standardisation of physiological rates to a common weight. Once physiological determinations were completed, soft tissues of each animal were dissected out and weighed after drying for $48 \mathrm{~h}$ at $80^{\circ} \mathrm{C}$ in an oven. All rates were then standardised to a common $200 \mathrm{mg}$ dry weight, following the expression:

$$
\mathrm{Ys}=\mathrm{Ye} \times(200 / \mathrm{We})^{b}
$$

where Ys is the rate for an animal of $200 \mathrm{mg}$, Ye is the physiological rate empirically measured, We is the dry weight of each animal used and $b$ is the power value obtained for the relationship between clearance rate and weight in cockles $(b=0.57)$.

\section{RESULTS}

\section{Diets}

Characteristics of diets used in this experiment are summarised in Table 1. A wide range of organic contents was covered, from 5 to $80 \%$ with mixed diets (Diets A to $\mathrm{H}$ ) and up to $90 \%$ when the monoalgal diet (Diet I) was included.

Since particle concentration was pre-fixed at $6.5 \mathrm{~mm}^{3}$ $\mathrm{l}^{-1}$ and given that the density of the inorganic fraction is higher, the particle concentration expressed in gravimetric terms and the organic content of the suspension were inversely related. In fact, great increases in the weight of ashed sediment only led to a slight increase in the packed volume occupied by this type of particle, and, therefore, the range of variation for TPM ( 3.5 to $23 \mathrm{mg} \mathrm{l}^{-1}$ ) in mixed diets was wider than that for POM (1 to $3 \mathrm{mg} \mathrm{l}^{-1}$ ).

\section{Food processing rates}

Mean values of filtration, rejection and ingestion rates of organic and total matter $\left(\mathrm{mg} \mathrm{h}^{-1}\right)$ are shown in Table 2. As expected, pseudofaeces were produced under all conditions tested. As a rule, filtration rates were higher when organic content of the diet was low.

Table 1. Characteristics of diets used in the experiment. VOL $\left(\mathrm{mm}^{3} \mathrm{l}^{-1}\right)$ : packed volume of suspended particles; TPM (mg $\left.\mathrm{l}^{-1}\right)$ : total particulate concentration; POM $\left(\mathrm{mg} \mathrm{l}^{-1}\right)$ : particulate organic matter; $f$ : organic content of particulate matter (POM/TPM); chl a $\left(\mu \mathrm{g} \mathrm{l}^{-1}\right)$ : concentration of chlorophyll $a$. Data are mean values $( \pm$ SD). Number of samples used for each diet given in parentheses

\begin{tabular}{|lrrrrr|}
\hline Diet & VOL & TPM & POM & $f$ & Chl $a$ \\
\hline A & 6.24 & 21.02 & 1.03 & 0.05 & 14.33 \\
$(4)$ & \pm 0.14 & \pm 1.94 & \pm 0.23 & \pm 0.01 & \pm 2.23 \\
B & 6.48 & 10.67 & 1.58 & 0.15 & 19.65 \\
$(4)$ & \pm 0.56 & \pm 1.16 & \pm 0.17 & \pm 0.01 & \pm 1.14 \\
C & 9.46 & 15.66 & 2.56 & 0.16 & 56.48 \\
$(6)$ & \pm 1.33 & \pm 2.12 & \pm 0.25 & \pm 0.02 & \pm 5.82 \\
D & 6.86 & 9.23 & 1.99 & 0.22 & 31.71 \\
$(4)$ & \pm 0.46 & \pm 1.05 & \pm 0.05 & \pm 0.02 & \pm 2.16 \\
E & 6.49 & 8.48 & 2.28 & 0.27 & 30.04 \\
$(4)$ & \pm 0.87 & \pm 1.88 & \pm 0.52 & \pm 0.04 & \pm 3.61 \\
F & 6.29 & 5.58 & 2.28 & 0.42 & 36.57 \\
$(4)$ & \pm 0.66 & \pm 1.34 & \pm 0.10 & \pm 0.09 & \pm 3.72 \\
G & 6.78 & 4.57 & 2.96 & 0.66 & 101.19 \\
$(6)$ & \pm 0.66 & \pm 0.83 & \pm 0.35 & \pm 0.08 & \pm 14.72 \\
H & 6.47 & 3.65 & 2.97 & 0.81 & 84.85 \\
$(4)$ & \pm 0.68 & \pm 0.18 & \pm 0.21 & \pm 0.02 & \pm 5.07 \\
I & 9.59 & 7.21 & 6.56 & 0.91 & 101.90 \\
$(5)$ & \pm 0.92 & \pm 1.01 & \pm 0.95 & \pm 0.01 & \pm 20.58 \\
\hline
\end{tabular}


Table 2. Cerastoderma edule. Filtration (Fr: $\mathrm{mg} \mathrm{h}^{-1}$ ), rejection $\left(\mathrm{Rr}: \mathrm{mg} \mathrm{h}^{-1}\right.$ ) and ingestion rates (Ir: $\mathrm{mg} \mathrm{h}^{-1}$ ) of the organic (OFr, ORr and OIr) and inorganic (IFr, IRr and IIr) components of the diet, and absorption rates (Ar) corresponding to each condition of those presented in Table 1. Values are means $\pm 95 \% \mathrm{CL}$. Number of samples used for each diet given in parentheses

\begin{tabular}{|c|c|c|c|c|c|c|c|}
\hline \multirow[t]{2}{*}{ Diet } & \multicolumn{2}{|c|}{ Fr } & \multicolumn{2}{|r|}{$\mathrm{Rr}$} & \multicolumn{2}{|c|}{ Ir } & \multirow[t]{2}{*}{$\mathrm{Ar}$} \\
\hline & OFr & IFr & ORr & IRr & OIr & IIr & \\
\hline $\begin{array}{l}\text { A } \\
(10)\end{array}$ & $\begin{array}{r}0.91 \\
\pm 0.26\end{array}$ & $\begin{array}{r}17.53 \\
\pm 5.06\end{array}$ & $\begin{array}{r}0.46 \\
\pm 0.18\end{array}$ & $\begin{array}{r}12.32 \\
\pm 4.74\end{array}$ & $\begin{array}{r}0.45 \\
\pm 0.10\end{array}$ & $\begin{array}{r}5.05 \\
\pm 0.58\end{array}$ & $\begin{array}{r}0.02 \\
\pm 0.08\end{array}$ \\
\hline $\begin{array}{l}B \\
(12)\end{array}$ & $\begin{array}{r}2.17 \\
\pm 0.22\end{array}$ & $\begin{array}{r}12.45 \\
\pm 1.28\end{array}$ & $\begin{array}{r}0.45 \\
\pm 0.09\end{array}$ & $\begin{array}{r}7.99 \\
+1.59\end{array}$ & $\begin{array}{r}1.72 \\
\pm 0.15\end{array}$ & $\begin{array}{r}4.47 \\
\pm 0.67\end{array}$ & $\begin{array}{r}1.10 \\
\pm 0.12\end{array}$ \\
\hline $\begin{array}{l}C \\
(12)\end{array}$ & $\begin{array}{r}2.44 \\
\pm 0.38\end{array}$ & $\begin{array}{r}12.51 \\
\pm 1.97\end{array}$ & $\begin{array}{r}0.50 \\
\pm 0.14\end{array}$ & $\begin{array}{r}7.14 \\
\pm 1.95\end{array}$ & $\begin{array}{r}1.94 \\
\pm 0.28\end{array}$ & $\begin{array}{r}5.38 \\
\pm 1.06\end{array}$ & $\begin{array}{r}1.30 \\
\pm 0.21\end{array}$ \\
\hline $\begin{array}{l}\mathrm{D} \\
(12)\end{array}$ & $\begin{array}{r}1.76 \\
\pm 0.19\end{array}$ & $\begin{array}{r}6.38 \\
\pm 0.68\end{array}$ & $\begin{array}{r}0.22 \\
\pm 0.06\end{array}$ & $\begin{array}{r}3.07 \\
\pm 0.90\end{array}$ & $\begin{array}{r}1.53 \\
\pm 0.14\end{array}$ & $\begin{array}{r}3.31 \\
\pm 0.54\end{array}$ & $\begin{array}{r}0.92 \\
\pm 0.13\end{array}$ \\
\hline $\begin{array}{l}\mathrm{E} \\
(12)\end{array}$ & $\begin{array}{r}1.49 \\
\pm 0.20\end{array}$ & $\begin{array}{r}4.07 \\
+0.55\end{array}$ & $\begin{array}{r}0.13 \\
\pm 0.09\end{array}$ & $\begin{array}{r}1.42 \\
\pm 0.75\end{array}$ & $\begin{array}{r}1.36 \\
\pm 0.14\end{array}$ & $\begin{array}{r}2.64 \\
\pm 0.47\end{array}$ & $\begin{array}{r}1.04 \\
\pm 0.14\end{array}$ \\
\hline $\begin{array}{l}F \\
(12)\end{array}$ & $\begin{array}{r}1.61 \\
\pm 0.27\end{array}$ & $\begin{array}{r}2.33 \\
\pm 0.39\end{array}$ & $\begin{array}{r}0.26 \\
\pm 0.14\end{array}$ & $\begin{array}{r}1.14 \\
\pm 0.36\end{array}$ & $\begin{array}{r}1.35 \\
\pm 0.17\end{array}$ & $\begin{array}{r}1.18 \\
\pm 0.19\end{array}$ & $\begin{array}{r}0.98 \\
\pm 0.15\end{array}$ \\
\hline $\begin{array}{l}\mathrm{G} \\
(11)\end{array}$ & $\begin{array}{r}1.83 \\
\pm 0.20\end{array}$ & $\begin{array}{r}0.99 \\
\pm 0.11\end{array}$ & $\begin{array}{r}0.17 \\
\pm 0.06\end{array}$ & $\begin{array}{r}0.24 \\
\pm 0.06\end{array}$ & $\begin{array}{r}1.66 \\
\pm 0.19\end{array}$ & $\begin{array}{r}0.76 \\
\pm 0.09\end{array}$ & $\begin{array}{r}1.31 \\
\pm 0.17\end{array}$ \\
\hline $\begin{array}{l}\mathrm{H} \\
(12)\end{array}$ & $\begin{array}{r}1.87 \\
\pm 0.24\end{array}$ & $\begin{array}{r}0.42 \\
\pm 0.05\end{array}$ & $\begin{array}{r}0.18 \\
\pm 0.06\end{array}$ & $\begin{array}{r}0.13 \\
\pm 0.03\end{array}$ & $\begin{array}{r}1.70 \\
\pm 0.25\end{array}$ & $\begin{array}{r}0.30 \\
\pm 0.05\end{array}$ & $\begin{array}{r}1.28 \\
\pm 0.23\end{array}$ \\
\hline $\begin{array}{l}\text { I } \\
(10)\end{array}$ & $\begin{array}{r}1.79 \\
\pm 0.59\end{array}$ & $\begin{array}{r}0.18 \\
\pm 0.06\end{array}$ & $\begin{array}{r}0.10 \\
\pm 0.07\end{array}$ & $\begin{array}{r}0.01 \\
\pm 0.01\end{array}$ & $\begin{array}{r}1.69 \\
\pm 0.61\end{array}$ & $\begin{array}{r}0.17 \\
\pm 0.06\end{array}$ & $\begin{array}{r}0.88 \\
\pm 0.37\end{array}$ \\
\hline
\end{tabular}

Filtration rates of organic matter were also dependent on the availability of organic matter in the diet, but to a much lesser extent than filtration rates of total matter, because the decrease of organic matter in diets of lower organic content was partially compensated for by higher pumping rates (Fig. 1). Despite the increasing proportion of rejected matter associated with higher filtration rates, there was still a slight positive dependence between ingestion rate and concentration

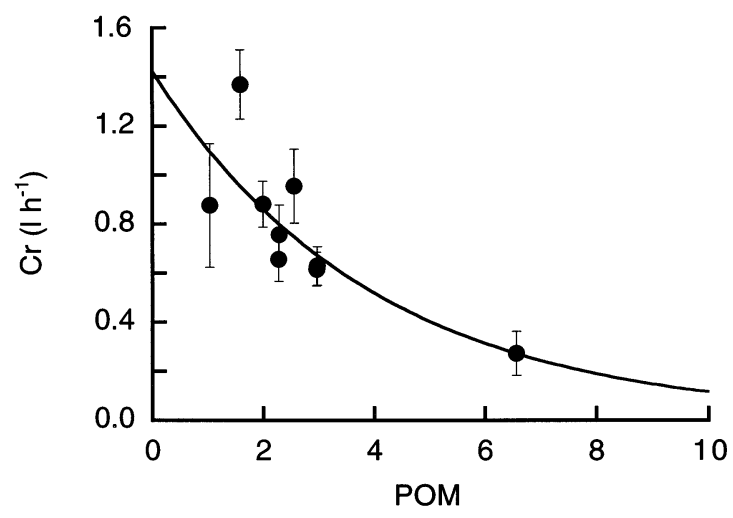

Fig. 1. Cerastoderma edule. Clearance rates $\left(\mathrm{l} \mathrm{h}^{-1}\right)$ as a function of POM values corresponding to each feeding condition. Plotted data are means $( \pm 95 \% \mathrm{CL})$. Line was drawn by eye of suspended matter. The ingestion rate of organic matter remained at values similar to those for the filtration rate of organic matter, since the proportion of filtered organic matter rejected, although variable, was always low (5 to $20 \%$ ), with the exception of rates for Diet A (close to $50 \%$ ). Absorption rate was maintained at about $1 \mathrm{mg} \mathrm{h}^{-1}$ for most diets. Diet A was again the exception $\left(0.023 \mathrm{mg} \mathrm{h}^{-1}\right)$ because, in addition to the lowest organic ingestion rates, absorption efficiency remained at values close to 0 .

\section{Preingestive selection}

Rejected proportions of different components of the seston (total particulate matter, organic matter and chlorophyll) corresponding to each condition are shown in Fig. 2. As a rule, the lower the organic content of filtered matter, the higher the proportion of matter that was rejected (both total and organic). This proportion varied from $5 \%$ in the diet with the highest organic content ( $f=0.9$ ) to $65 \%$ for the diet with the lowest organic content $(f=0.05)$. Rejected proportions for organic matter showed a similar trend but always represented lower values (ORr/OFr $<\mathrm{Rr} / \mathrm{Fr}$ ). The proportion of rejected chlorophyll, however, did not seem to vary with the quality of the food. Mean values of the proportion of filtered chlorophyll that was rejected were lower than those values corresponding to organic matter. In addition, it can be seen that differences between the 2 percentages of rejection were higher for diets with lower organic contents. Selection efficiencies of organic matter (SEo) and chlorophyll a (SEchl) are represented as a function of the organic content of the food in Fig. 3. Trends shown by both efficiencies are coincident for medium to high organic

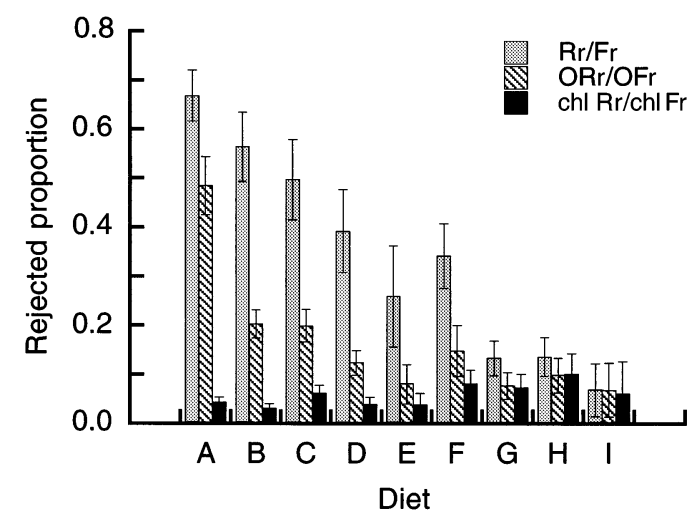

Fig. 2. Cerastoderma edule. Proportions of filtered matter rejected, calculated for total (Rr/Fr), organic (ORr/OFr) and chlorophyllic (chlRr/chlFr) matter. Plotted data represent mean values $( \pm 95 \% \mathrm{CL})$ 


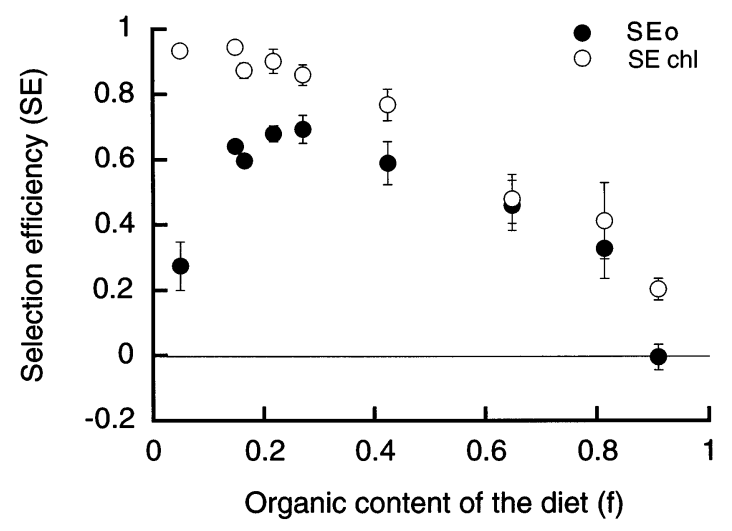

Fig. 3. Cerastoderma edule. Mean values ( $\pm 95 \%$ CL) of selection efficiency index calculated on the basis of chlorophyll (SEchl) and overall organic matter (SEo) as a function of the organic content of the diet

contents, where selection efficiencies increased when $f$ decreased; for low organic contents, however, the 2 indexes diverged, differences being higher the lower the organic content of the diet, whereas SEchl stayed at maximum values when $f$ decreased. SEo exhibited a maximum value when $f=0.22$ and then declined when organic content of the diets decreased.

\section{Pseudofaecal mucus production}

Pseudofaecal mucus production was dependent on rejection rate (total) and organic content of the filtered suspension, according to the following power function:

$$
\begin{gathered}
\mathrm{Mr}=0.1016 \mathrm{Rr}^{0.9684( \pm 0.046)} f^{0.4131( \pm 0.0758)} \\
\left(\mathrm{r}^{2}=0.9351, \mathrm{n}=84, \mathrm{p}=10^{-4}\right)
\end{gathered}
$$

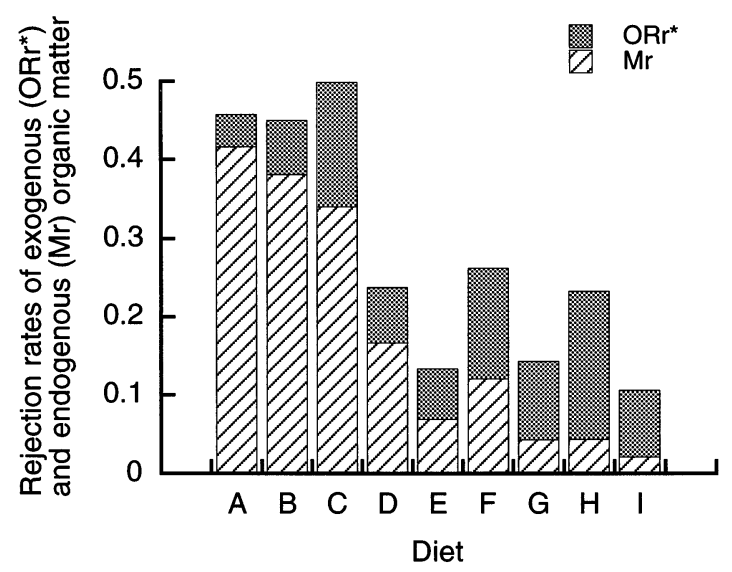

Fig. 4. Cerastoderma edule. Rate of rejection of organic matter in pseudofaeces expressed as the sum of its 2 components: organic matter coming from the diet or exogenous organic matter $\left(\mathrm{ORr}^{*}\right)$, and mucus or endogenous organic matter $(\mathrm{Mr})$, measured for each dietary condition
Formulation of this dependence as a power function allowed a good fit to data and also had the merit of predicting a null production of pseudofaecal mucus when no pseudofaeces were produced $(\mathrm{Rr}=0)$. Eq. (1) predicts a mucus production that is almost proportional to the rejection rate, because the power value for this parameter is close to 1 . In fact, confidence limits calculated for the estimated value of the power included $b=$ 1 , so a strict proportionality cannot be discarded. The relationship between pseudofaecal mucus production and total rejection rate was also dependent on the organic content of the feeding suspension. For example, at a given rate of production of pseudofaeces, the mucus production rate would be $56 \%$ lower if the organic content of the diet were $20 \%$ instead of $80 \%$.

Pseudofaecal mucus production might be negligible in terms of total weight of rejected matter, but it significantly contributes to the organic rejection rate, especially when the organic content of the diet is low. Rates of organic matter rejection corresponding to each condition are shown in Fig. 4 as the sum of 2 components: filtered organic matter that is rejected (or exogenous: $\mathrm{ORr}^{*}$ ) and pseudofaecal mucus production (or endogenous: Mr). When the organic content of the diet is low, mucus constitutes the main fraction of the organic content of pseudofaeces.

Biasing effects derived from the significant presence of mucus may be clearly seen in the data summarised in Table 3. We have presented the proportion that

Table 3. Cerastoderma edule. Mean values ( $\pm 95 \%$ CL) of actually measured organic ingestion (OIr) and absorption rates (Ar) as a proportion of 'true' rates of organic ingestion $\left(\mathrm{OIr}^{*}\right)$ and absorption $\left(\mathrm{Ar}^{*}\right)$. True rates should be taken as rates corrected for the presence of mucus in the pseudofaeces. Number of samples used for each diet given in parentheses

\begin{tabular}{|lcr|}
\hline Diet & OIr/OIr & \\
\hline $\mathrm{A}$ & 53.8 & $\mathrm{Ar} / \mathrm{Ar}^{*}$ \\
$(10)$ & \pm 6.0 & 1.4 \\
$\mathrm{~B}$ & 82.3 & \pm 13.7 \\
$(12)$ & \pm 2.6 & 74.9 \\
$\mathrm{C}$ & 85.3 & \pm 2.7 \\
$(12)$ & \pm 2.5 & 79.6 \\
$\mathrm{D}$ & 90.4 & \pm 3.0 \\
$(12)$ & \pm 2.0 & 85.1 \\
$\mathrm{E}$ & 95.5 & \pm 2.6 \\
$(12)$ & \pm 2.0 & 94.3 \\
$\mathrm{~F}$ & 92.6 & \pm 2.3 \\
$(12)$ & \pm 3.4 & 90.3 \\
$\mathrm{G}$ & 97.5 & \pm 4.0 \\
$(11)$ & \pm 0.8 & 96.8 \\
$\mathrm{H}$ & 97.4 & \pm 0.9 \\
$(12)$ & \pm 0.9 & 96.5 \\
$\mathrm{I}$ & 98.2 & \pm 1.1 \\
$(10)$ & \pm 2.1 & 96.5 \\
\hline
\end{tabular}


measured rates of organic ingestion (OIr) and absorption (Ar) represent with respect to corrected values of those 2 parameters (OIr* and $\mathrm{Ar}^{*}$, respectively). Underestimation is minor when the organic content of the diet is medium to high (Diets E to I), but it is certainly important when the diet is mainly composed of inorganic matter, reaching values of $46 \%$ in terms or organic ingestion and $98.6 \%$ in terms of rate of absorption.

\section{Benefits derived from selection processes}

Values for the BR index, calculated in terms of overall organic matter (BRo) and also chlorophyll (BRchl) are represented in Fig. 5. Benefits derived from selection processes are more evident for diets of low organic content. For example, in Diet A, ingestion of algal cells is raised by $65 \%$ over the phytoplankton ingestion that would occur if the selection mechanism were not operating.

\section{Absorption rate and efficiency}

The rate of absorption of ingested organic matter depends on the absorption efficiency, which, in turn, depends on the organic content of ingested matter (Fig. 6). When the organic content of ingested matter is low, the efficiency with which organic matter is absorbed is also low, and rises towards an asymptotic maximum value as organic matter constitutes a higher fraction of total ingestion. Data graphed in Fig. 6A were fitted to the following hyperbolic function:

$$
\begin{gathered}
\mathrm{AE}=0.8598-0.0621( \pm 0.0022) / i \\
\left(\mathrm{r}^{2}=0.8962, \mathrm{n}=93\right)
\end{gathered}
$$

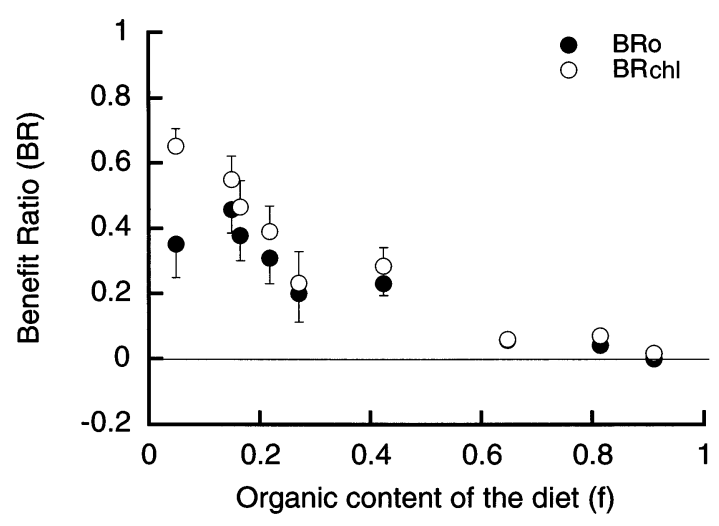

Fig. 5. Cerastoderma edule. Mean values ( $\pm 95 \%$ CL) of benefit ratio indexes calculated on the basis of overall organic matter (BRo) and chorophyll (BRchl). See 'Material and methods' for further explanation of the BR index
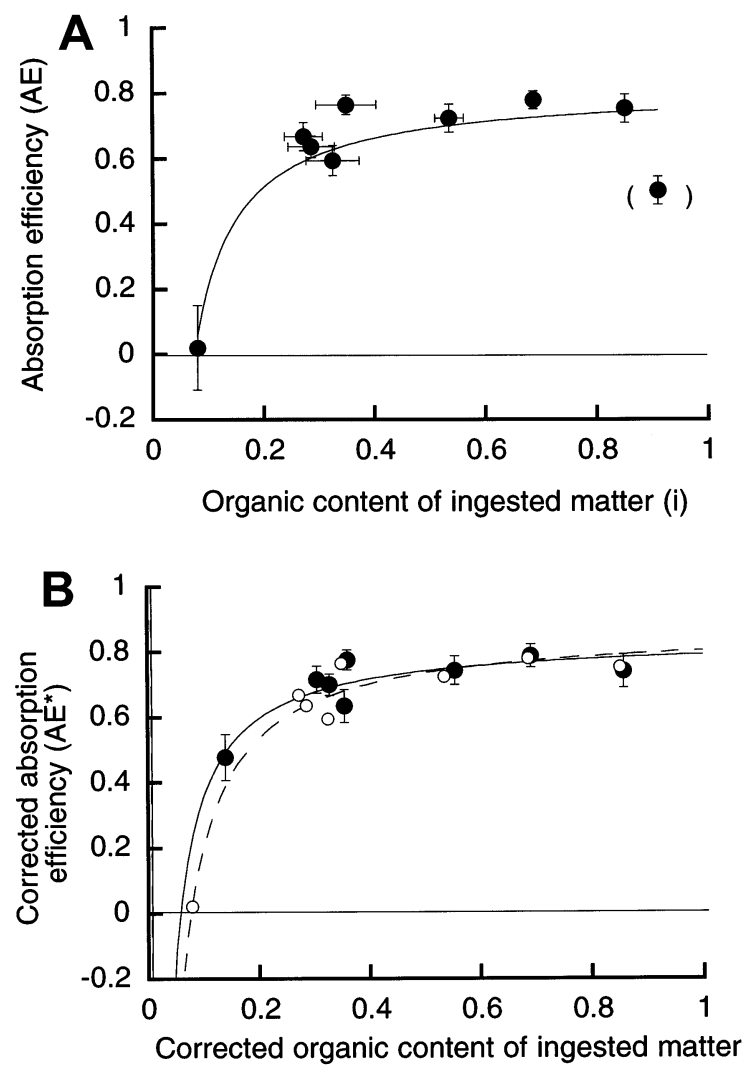

Fig. 6. Cerastoderma edule. (A) Absorption efficiency (AE) as a function of the organic content of ingested matter (i). (B) Corrected values estimated for absorption efficiency $\left(\mathrm{AE}^{*}\right)$, as a function of corrected values of the organic content of ingested matter. Applied correction was based on subtracting the organic fraction of mucus from pseudofaeces and adding it to both organic ingestion and absorption rates. Plotted values in both panels correspond to means ( $\pm 95 \%$ CL) obtained for each feeding condition; curves were fitted to individual data (see Eqs. $2 \& 3$ ). To make comparison easier, data from A were superimposed on $\mathrm{B}$ as open circles and a dashed line

The asymptotic value in this function (see 'Material and methods') can be taken as the gross absorption efficiency $(86 \%)$, and the coefficient 0.0621 represents the percentage $(6.21 \%)$ of endogenous faecal losses compared with the weight of total ingested matter. Absorption efficiencies estimated after discounting the effect of the mucines $\left(\mathrm{AE}^{*}\right)$ are represented in Fig. $6 \mathrm{~B}$, together with net efficiencies directly estimated, in order to make comparison easier.

As was expected, the newly fitted curve is shifted to the left with respect to the previous curve, towards lower values of organic content of the food and corresponding higher values of absorption efficiency. The equation fitted to corrected values was:

$$
\begin{gathered}
\mathrm{AE}^{*}=0.8445-0.0479( \pm 0.0037) / i \\
\left(\mathrm{r}^{2}=0.6729, \mathrm{n}=85\right)
\end{gathered}
$$



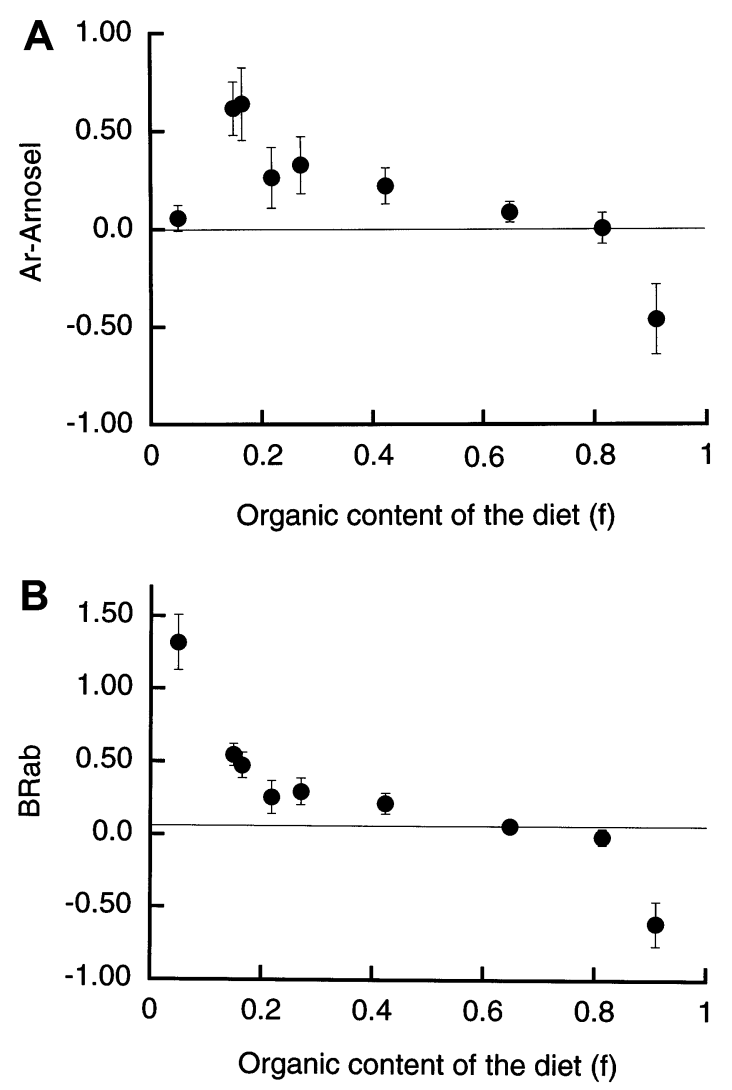

Fig. 7. Cerastoderma edule. (A) Mean values of the difference in absorption rate that would have resulted if cockles were not selective feeders and limited ingestion rate by reducing clearance rate, by comparison with actually measured rates of absorption. Data are shown as a function of the organic content of the diet. (B) Proportion of actually recorded absorption rates which are derived from selection processes operating at the preingestive level. Data, based on values presented in $\mathrm{A}$, are graphed as a function of the organic content of the diet

As regards phytoplankton absorption, we can say that Tetraselmis suecica is absorbed with a relatively high efficiency, even when it composes only a minor fraction of ingested matter. In fact, AE for the monoalgal diet was clearly lower than for any mixed diet, and, therefore, data corresponding to this diet were not taken into account when fitting the curve for absorption efficiency.

\section{Benefits of preingestive selection processes at the digestive level}

We have represented in Fig. 7A those values corresponding to the difference between actual rates of absorption (Ar) and those rates that would have been obtained if selection processes were not operating (Arnosel, obtained using equations presented in the previous section). Benefits derived from preferential rejection of inorganic matter are more evident when the organic content of the diet is low, although there is a clear decrease when the organic content is as low as 0.05 . However, to compare results obtained under different conditions it is better to use relative magnitudes, such as the proportion of recorded absorption rates which are derived from preingestive selection processes; this is in fact what we have termed BRab, and the values are presented in Fig. 7B. A clear trend can be observed; the index increases when the organic content of the diet decreases and may eventually reach values $>1$. Comparison of BRab (Fig. 7B) with BRo (Fig. 5) indicates that the resultant benefit is higher in terms of absorption than in terms of ingestion of organic matter.

\section{DISCUSSION}

The ability of bivalves to modify their feeding and digestive behaviour in response to changes in the quantity and quality of the particulate matter in suspension is well known. As in previous investigations (Navarro \& Iglesias 1993, Urrutia et al. 1996, Navarro \& Widdows 1997), and in contradiction of some scientists who reject the concept of physiological regulation of feeding (Clausen \& Riisgard 1996, Jørgensen 1996), we found in the present experiments that cockles increase processing rates when faced with an increase in particulate matter associated with a decrease in the quality of the suspension. Regulation of ingestion rate by means of keeping high rates of rejection coupled to high rates of filtration leads to a significant increment in the organic fraction of ingested matter, which, in turn, enhances the efficiency of digestive processes. Extrapolation of these results to other species of bivalves would not be justified, but in a comparative study of 3 species of bivalves (Hawkins et al. 1998a), it was found that basic traits of feeding behaviour were similar in cockles, mussels and oysters.

The ability to alter the composition of ingested matter by preferentially rejecting some given components of the diet has been proved for several species of bivalves (Kiørboe \& Møhlenberg 1981, Newell \& Jordan 1983, Prins et al. 1991, Iglesias et al. 1992, Urban \& Kirchman 1992, Bayne et al. 1993, MacDonald \& Ward 1994, Hawkins et al. 1996, 1998b, Bacon et al. 1998). Utilisation of endoscopes combined with image analysis systems led to the 'in vivo' observation of processes taking place in the gills of bivalves and contributed significantly to the understanding of basic aspects of the functioning of the filtering apparatus of bivalves (Beninger et al. 1992, Beninger \& St-Jean 1997a,b, Ward et al. 1993, 1994, Ward 1996). The mechanisms 
underlying preingestive qualitative selection, however, have not been elucidated yet for the eulamellibranch gill.

\section{Pseudofaecal mucus production}

Mucus production in bivalves has been studied in depth since the 1990s as an approach to better understand the role of mucus in particle processing, including mucocyte mapping for some species (Beninger \& St-Jean 1997a,b, Beninger et al. 1997). However, no quantification of this type of secretion or its consequences has been presented. Pseudofaeces production is not free of energetic expense, because it necessitates rejection of endogenous organic matter. There are 2 main factors that have an effect on pseudofaecal mucus losses: the quantity of matter rejected per unit time (this dependence is almost linear) and the organic content of suspended matter. This second effect could be related to the potential function of the mucus as a pseudofaeces-compacting agent (Ward 1996). Due to its higher density, inorganic matter occupies a smaller volume than organic matter, and so, for a given mass of pseudofaeces, the quantity of mucus needed to pack low organic content matter would be smaller.

Energetic costs of pseudofaeces production could, in fact, explain the differential response shown by Cerastoderma edule to rising concentrations of suspended matter of different organic content. Under conditions where pseudofaeces production does not lead to a significant enrichment of ingested matter (high organic content suspensions), loss of organic matter in the form of mucus could offset the benefits derived from selective processes or even result in a net loss of organic matter; therefore, a strategy based on the reduction of the clearance rate is clearly more beneficial. When suspended organic matter composes a minor fraction of total suspended matter, however, energy losses associated with the mucus rejected with pseudofaeces are, for the most part, compensated for by the increase in the organic content that results from the preferential rejection of inorganic matter. This enrichment has in addition a positive effect on absorption efficiency.

There is evidence, however, pointing towards a limit to this kind of response. Prins \& Smaal (1989) found negative absorption efficiencies for carbon in cockles at the most extreme conditions of organic dilution, which the authors explained as an effect derived from the large quantities of mucus produced to reject the copious pseudofaeces observed under those extreme conditions. Under the food conditions tested in the present study, where the maximum particle concentration used was $23 \mathrm{mg} \mathrm{l}^{-1}$, we did not, however, observe negative balances, except when the monoalgal diet was supplied; here an inability to select among a homogeneous suspension of particles led to a loss of energy as mucus associated with the production of small amounts of pseudofaeces, which was not compensated for in terms of an increment of organic content in the ingested matter. For the remaining conditions, the investment in the endogenous organic matter required to reject pseudofaeces was energetically advantageous (positive values of the BRo index). Conditions under which the greatest mucus production was observed were in fact the same conditions for which maximum organic enrichment was achieved when compared with results that presumably would have been reached if the ingestion rate had been regulated by reducing the clearance rate.

\section{Computation of pseudofaecal mucus production: methodological implications}

Until now, as far as we know, it was assumed that the contribution of mucus to pseudofaeces was negligible, and, therefore, it was considered that all organic matter rejected was exogenous matter. This assumption may be acceptable when the main objective of the study centres on determining the global energy balance, since, in that case, establishing differences in the type of organic matter depending on its endogenous or exogenous origin is not relevant. However, when the objectives of the study include an analysis of the treatment that different components of the diet receive, computation of mucus in pseudofaeces is important. We found that the presence of mucus explained why measured net and gross selection efficiencies diverged when the organic contents of the diet were low: the reduction in the selection efficiency of organic matter observed for low organic contents was only apparent, and actually resulted from an artefact caused by the mucus content of the pseudofaeces and not from a real loss of the efficiency of preingestive sorting processes.

Futhermore, when mucines are not computed, rates of ingestion and absorption as well as absorption efficiencies are underestimated, the underestimation becoming more important the larger the quantity of rejected matter as pseudofaeces; as shown in Table 3, for organic contents $<15 \%$, differences between corrected and uncorrected values are high, especially when considered in terms of absorption rates. As a result, absorption efficiencies will also be underestimated to a considerable extent in the case of diets that induce the production of large quantities of pseudofaeces (see Fig. 6). Any comparison with conditions under which the production of pseudofaeces was not observed should be done with estimates obtained after discounting the mucus from the pseudofaeces 


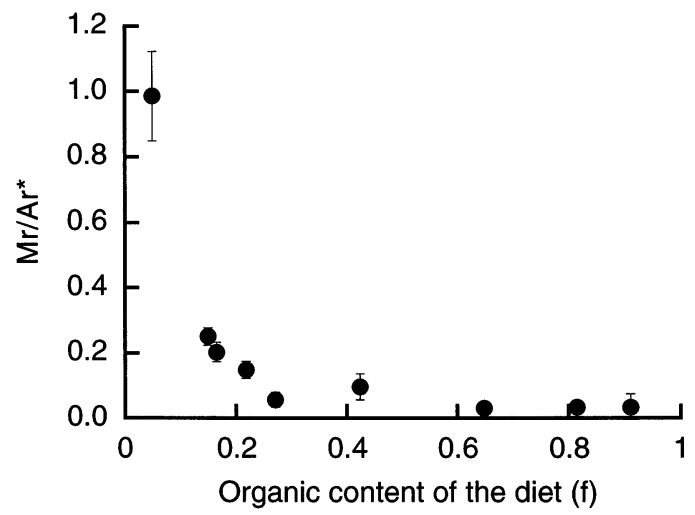

Fig. 8. Cerastoderma edule. Mucus rejected (Mr) in pseudofaeces as a proportion of corrected values of absorption rate $\left(\mathrm{Ar}^{*}\right)$. Mean values $( \pm 95 \% \mathrm{CL})$ are shown in relation to the organic content of the diet

and recalculating all processing rates affected by this component.

The relevance of the presence of mucus is more evident when presented as a percentage with respect to true absorption (Fig. 8): the lower the organic content of the suspension, the more important the fraction represented by mucus, in some cases reaching up to $98 \%$ of the true absorption rate. These data clearly show that, depending on the feeding conditions, mucus production, far from being negligible, would appear to be the main factor determining the net quantity of energy fluxes through the animal. However, precisely under these conditions the maximum benefit from selective processes is achieved, as indicated by enrichment indexes (see Figs. 5 \& 7B), and therefore the investment is for the most part compensated.

\section{Absorption of food}

To evaluate the benefits derived from different preingestive responses in global terms, it is necessary to also consider digestive processes, since those are the processes that ultimately determine energy acquisition and hence growth. Absorption rate depends on ingestion rate, and absorption efficiency represents the 2 interrelated parameters. We did not find any relationship between ingestion rate and absorption efficiency, due probably to the small range of variation in ingestion rate that resulted from the control exerted at the preingestive level. Dependence on the quality of ingested matter, however, was evident: absorption efficiency increased with the increment in organic content of ingested matter, according to a hyperbolic function. This kind of function fitted some theoretical considerations presented in the 'Material and methods'. The hyperbolic-like dependence between absorption efficiency and organic content of ingested matter makes clear the great importance of the capability of cockles to increase the organic content of the diet by preferentially rejecting inorganic matter in the pseudofaeces, since small variations in the organic content will have dramatic effects on the efficiency with which ingested matter is absorbed. So, a very small difference in the organic content in the range of low values may determine the magnitude of the absorption rate and even whether this absorption rate will be positive or negative. Briefly, the benefits derived from preingestive selection processes tend to be magnified at the digestive level, since the absorption rate may be augmented to a greater extent than the rate of ingestion, as can be deduced by comparing values for BRab and BRo indexes.

\section{Conclusions}

Cockles feed selectively. Preferential ingestion of phytoplankton was observed under a broad range of conditions, but selection efficiency was maximum when the organic content of the diet $(f)$ was low, and declined for increasing values of $f$. This selective behaviour has a great adaptive value, since it permits Cerastoderma edule to maintain positive rates of energy acquisition under conditions where dilution of organic matter would otherwise lead to negative rates of absorption. This feeding behaviour is not free of energetic expense, since rejection of pseudofaeces results in some loss of energy to the environment in the form of mucus. Moreover, the tradeoff between the investment in mucus and the benefits derived from preingestive selection processes may ultimately determine bivalve feeding strategies.

Acknowledgements. We thank Dr M. M. Ortega for assistance with the language and style. A draft version benefited from comments made by Dr Beninger and by suggestions from 3 anonymous referees. This study was funded by a project (RU-1998-6) from the Departamento de Educación, Universidades e Investigación of the Basque Government.

\section{LITERATURE CITED}

Bacon GS, MacDonald BA, Ward JE (1998) Physiological responses of infaunal (Mya arenaria) and epifaunal (Placopecten magellanicus) bivalves to variations in the concentration and quality of suspended particles. J Exp Mar Biol Ecol 219:105-125

Bayne BL, Hawkins AJS, Navarro E (1987) Feeding and digestion by the common mussel Mytilus edulis L. Oecologia 37:137-162

Bayne BL, Iglesias JIP, Hawkins AJS, Navarro E, Heral M, Deslous-Paoli JM (1993) Feeding behaviour of the mussel, 
Mytilus edulis L.: responses to variations in quantity and organic content of the seston. J Mar Biol Assoc UK 73: 813-829

Beninger PG, St-Jean SD (1997a) Particle processing on the labial palps of Mytilus edulis and Placopecten magellanicus (Mollusca: Bivalvia). Mar Ecol Prog Ser 147:117-127

Beninger PG, St-Jean SD (1997b) The role of mucus in particle processing by suspension-feeding marine bivalves: unifying principles. Mar Biol 129:389-397

Beninger PG, Le Pennec M, Donval A (1991) Mode of particle ingestion in five species of suspension-feeding bivalve molluscs. Mar Biol 108:255-261

Beninger PG, Ward JE, MacDonald BA, Thompson RJ (1992) Gill function and particle transport in Placopecten magellanicus (Mollusca: Bivalvia) as revealed using video endoscopy. Mar Biol 114:281-288

Beninger PG, St-Jean S, Poussart Y, Ward JE (1993) Gill function and mucocyte distribution in Placopecten magellanicus (Mollusca: Bivalvia): the role of mucus in particle transport. Mar Ecol Prog Ser 98:275-282

Beninger PG, Dufour SC, Bourque J (1997) Particle processing mechanisms of the eulamellibranch bivalves Spisula solidissima and Mya arenaria. Mar Ecol Prog Ser 150: 157-169

Clausen I, Riisgard HU (1996) Growth, filtration and respiration in the mussel Mytilus edulis: no evidence for physiological regulation of the filter-pump to nutritional needs. Mar Ecol Prog Ser 141:37-45

Davies MS, Hawkins SJ (1998) Mucus from marine molluscs. Adv Mar Biol 34:1-71

Davies MS, Jones HD, Hawkins SJ (1990) Seasonal variation in the composition of pedal mucus from Patella vulgata $\mathrm{L}$. J Exp Mar Biol Ecol 144:101-112

Hawkins AJS, Navarro E, Iglesias JIP (1990) Comparative allometries of gut content, gut passage time and metabolic faecal loss in Mytilus edulis and Cerastoderma edule. Mar Biol 105:197-204

Hawkins AJS, Smith RFM, Bayne BL, Heral M (1996) Novel observation underlying the fast growth of suspensionfeeding shellfish in turbid environments: Mytilus edulis. Mar Ecol Prog Ser 131:179-190

Hawkins AJS, Bayne BL, Brougrier S, Heral M, Iglesias JIP, Navarro E, Smith RFM, Urrutia MB (1998a) Some general relationships in comparing the feeding physiology of suspension-feeding bivalve molluscs. J Exp Mar Biol Ecol 219:87-103

Hawkins AJS, Smith RFM, Tan SH, Yasin ZB (1998b) Suspension-feeding behaviour in tropical bivalve molluscs: Perna viridis, Crassostrea belcheri, Crassostrea iradelei, Saccostrea cucculata and Pinctata margarifera. Mar Ecol Prog Ser 166:173-185

Iglesias JIP, Navarro E, Alvarez Jorna P, Armentia I (1992) Feeding, particle selection and absorption in cockles Cerastoderma edule exposed to variable conditions of food concentration and quality. J Exp Mar Biol Ecol 162:177-198

Editorial responsibility: Otto Kinne (Editor), Oldendorf/Luhe, Germany
Jørgensen CB (1996) Bivalve filter feeding revisited. Mar Ecol Prog Ser 142:287-302

Kiørboe T, Møhlenberg F (1981) Particle selection in suspension-feeding bivalves. Mar Ecol Prog Ser 5:291-296

Lorenzen CJ (1967) Determination of chlorophyll and pheophytin: spectrophotometric equations. Limnol Oceanogr 30:693-698

MacDonald BA, Ward JE (1994) Variation in food quality and particle selectivity in the sea scallop Placopecten magellanicus (Mollusca: Bivalvia). Mar Ecol Prog Ser 108: 251-264

Navarro E, Iglesias JIP (1993) Infaunal filter-feeding bivalves and the physiological response to short-term fluctuations in food availability and composition. In: Dame RF (ed) Bivalve filter feeders in estuarines and coastal ecosystem processes. NATO ASI Series, Vol G 33. Springer-Verlag, Berlin, p 25-26

Navarro JM, Thompson RJ (1994) Comparison and evaluation of different techniques for measuring absorption efficiency in suspension feeders. Limnol Oceanogr 39: 159-164

Navarro JM, Widdows J (1997) Feeding physiology of Cerastoderma edule in response to a wide range of seston concentrations. Mar Ecol Prog Ser 152:175-186

Newell RIE, Jordan SE (1983) Preferential ingestion of organic material by the American oyster Crassostrea virginica. Mar Ecol Prog Ser 13:47-53

Peck LS, Prothero-Thomas E, Hough N (1993) Pedal mucus production by the Antarctic limpet Nacella concinna (Strebel, 1908). J Exp Mar Biol Ecol 174:177-192

Prins TC, Smaal AC (1989) Carbon and nitrogen budgets of the mussel Mytilus edulis L. and the cockle Cerastoderma edule (L.) in relation to food quality. In: Ross J (ed) Topics in marine biology. Sci Mar 53:477-482

Prins TC, Smaal AC, Pouwer AJ (1991) Selective ingestion of phytoplankton by the bivalves Mytilus edulis L. and Cerastoderma edule (L.). Hydrobiol Bull 25:93-100

Urban ER, Kirchman DL (1992) Effect of kaolinite clay on the feeding activity of the eastern oyster Crassostrea virginica (Gmelin). J Exp Mar Biol Ecol 160:47-60

Urrutia MB, Iglesias JIP, Navarro E, Prou J (1996) Feeding and absorption in Cerastoderma edule under environmental conditions in the Bay of Marennes-Oleron (western France). J Mar Biol Assoc UK 76:431-450

Ward JE (1996) Biodynamics of suspension-feeding in adult bivalve molluscs: particle capture, processing, and fate. Invertebr Biol 115:218-231

Ward JE, MacDonald BA, Thompson RJ, Beninger PG (1993) Mechanisms of suspension feeding in bivalves: resolution of current controversies by means of endoscopy. Limnol Oceanogr 38:265-272

Ward JE, Newell RIE, Thompson RJ, MacDonald BA (1994) In vivo studies of suspension-feeding processes in the eastern oyster, Crassostrea virginica (Gmelin). Biol Bull 186: $221-240$

Submitted: December 28, 1999; Accepted: June 27, 2000 Proofs received from author(s): November 29, 2000 